Narrative Works

Issues, Investigations, \& Interventions

\title{
Narrative Relations and Associations: Catherine Kohler Riessman's Research Dialogism
}

\section{Cigdem Esin and Corinne Squire}

Volume 10, 2020

Special Issue: Amor Narratio: A Festschrift For Catherine Kohler Riessman

URI: https://id.erudit.org/iderudit/1076922ar

DOI: https://doi.org/10.7202/1076922ar

See table of contents

Publisher(s)

Centre for Interdisciplinary Research on Narrative, St. Thomas University

ISSN

1925-0622 (digital)

Explore this journal

Cite this article

Esin, C. \& Squire, C. (2020). Narrative Relations and Associations: Catherine Kohler Riessman's Research Dialogism. Narrative Works, 10, 107-116.

https://doi.org/10.7202/1076922ar
Article abstract

In this paper, Esin and Squire provide their individual and collective reflections on the influence of Catherine Kohler Riessman's dialogical approach in research. Each researcher reinterpreted the dialogism in Riessman's approach in their own work, focusing on differing elements of it. While Esin examines her experience of relationality, reflexivity, and positionality in her work, Squire discusses her adoption of the approach to develop methodological interdisciplinarity in social science research. The authors then reflect on their dialogue in researching multimodal narratives, historical positioning in and beyond narratives, and power relations in the context of research.
This document is protected by copyright law. Use of the services of Érudit (including reproduction) is subject to its terms and conditions, which can be viewed online.

https://apropos.erudit.org/en/users/policy-on-use/ 


\title{
SPECIAL ISSUE
}

AMOR NARRATIO: A FESTSCHRIFT FOR

CATHERINE KOHLER RIESSMAN

\section{Narrative Relations and Associations: Catherine Kohler Riessman's Research Dialogism}

\author{
Cigdem Esin \& Corinne Squire \\ University of East London
}

\begin{abstract}
In this paper, Esin and Squire provide their individual and collective reflections on the influence of Catherine Kohler Riessman's dialogical approach in research. Each researcher reinterpreted the dialogism in Riessman's approach in their own work, focusing on differing elements of it. While Esin examines her experience of relationality, reflexivity, and positionality in her work, Squire discusses her adoption of the approach to develop methodological interdisciplinarity in social science research. The authors then reflect on their dialogue in researching multimodal narratives, historical positioning in and beyond narratives, and power relations in the context of research.
\end{abstract}

Keywords:

Dialogism, relationality, reflexivity, positionality, interdisciplinarity

Catherine Kohler Riessman has been a guiding figure for much of our work in the Centre for Narrative Research (CNR) at the University of East London. In our personal and collective work and lives, she has been extraordinarily supportive and inspiring. Here, we explicate what we see have affected our own work, that of many other researchers, and, we believe, that of many narrative researchers to come.

Esin's first encounter with Riessman's work (see Riessman 1993, 2002, 2008) was when she was working on her doctoral research, for which she collected sexual stories from two generations of women in modern Turkey. Riessman's thoughts on dialogic approaches to storytellers and their many audiences, the co-construction of stories, narrative positioning, and the role of the researcher as one of the co- 
creaters of individual stories immediately hit her. The framework drawn up by Riessman's methodological questioning has been her guide since those years. Esin has been using multimodal narratives, involving the inclusion of visual, relational, and contextual narratives into the analysis of stories told in research environments (Esin, 2017; Esin \& Lounasmaa, 2020; Esin \& Squire, 2013).

In her work, including the collaborative papers with Squire, Esin has been interested in the more personal stories which are constituted in study environments. Working with those narratives pushes researchers to examine the circumstances and relationships that constitute individual narratives. Esin has also been interested in the interconnections between personal and public, due to her sociology training in Turkey, in which personal stories were always connected to grand political narratives. Reading Riessman's work gave Esin the insight to consider dialogue as a form of freedom beyond the interpersonal dialogue of the researcher and researched. The voice of the story travels to multiple audiences, yet the affect of the researcher's and storyteller's positioning may draw storylines. For Esin, it was a requirement to look into the complexity of that particular power relation. Riessman's perpective on research dialogue has been a valuable source to work with.

Squire began reading and working with Riessman's work in the late 1990s. Again, the dialogism of Riessman's approach, in relation to different disciplines, modalities, forms of language, and contexts, was pivotal for her when she was trying to adopt a more interdisciplinary social sciences framework; starting to work with visual methods; trying to think about the language genres characterizing research participants' interviews; and attempting to link up such work with the broader context of narratives within which people live. She was particularly affected by Riessman's insistence on the media of stories - their specific verbal and/or visual languages. At a time when a great deal of narrative work was focusing almost exclusively on content, Riessman, particularly in her 2008 synthesis of the narrative research field, brought together these lines of study. At the same time, Riessman's cognizance of "contextual" factors, which for Squire translate to the power relations of narrative, has been consistent, especially across the last 20 years of her work. For Squire, then, Riessman's work from the 1990s and her development of it during the 2000s has offered theoretical and methodological support, and highly generative ideas about how to work differently.

This is a collaborative - and itself dialogic - paper for several reasons. Esin and Squire have worked together in studies that brought 
their interests together-first, by exploring the use and function of multimodal narratives. Esin was especially interested in contributing to the broadening of research spaces by moving beyond a single tool of language while working with multilingual participants. Multimodality was a useful approach to multiply narrative tools. Second, those studies involved the literal transection of socioeconomic spaces in East London by personal stories of those spaces, generated by participants located at different points on the transect. Squire was particularly concerned with how those stories stayed in place, resisted place, or simply moved out of place, tangentially to existing power relations. Third, the practice of narrative methodology and perspective necessitates both a period of refinement with an experienced researcher and the renewal of research discourses and practices by work with colleagues with different histories and expertise. Narrative researchers are not only careful listeners; they are also meticulous facilitators of relationships. Squire has offered valuable comprehension to Esin's research experience by her curiosity and sensitivity to individual spaces and narratives. Esin has gifted to Squire's work the example of a reflective and a historically tuned voice that thus extends in two directions the possibilities of narrative research dialogue.

\section{Who Tells the Story? Why Is It Relational? Complexifying the Narrative Research Field}

Positioning has been an important aspect of co-creating life narratives in Esin's (2009) analyses. While she was collecting individual sexual stories, she constantly thought about the interview context and the positions both the participants and she herself inhabited in modern Turkey. Participants' and researcher's understandings of being modern, for instance, differentiated and shaped each story differently for that research; there was no general "we" position. Esin realized also how the entire research community of participants and researcher in each context set its own contours, and how positions of participants and researchers are not stable or universal within their contexts. In her further research, she has continued to identify multiple positions at play among and between researchers and participants.

It was Riessman's (2002) reflexive questioning of her position as a Western researcher that led her to consider South Asian childless women's narratives outside the dominant understanding of being a mother. Telling their stories was not an empowerment for either research participants or researchers, as some researchers had read stories in other 
contexts (Williams et al., 2003). Those stories were strategies to challenge the hegemony of the "motherhood" notion. Cultural difference, Riessman emphasizes, should be considered while being an audience to those stories. In Esin's work on sexual stories in Turkey (Esin, 2009), young Muslim women's narratives of living in East London (Esin, 2017), and refugee narratives of migration (Esin and Lounasmaa, 2020), she has put the politics of storytelling under scrutiny. Esin's main questions have been similar in these contexts: Who tells the story? How does the audience contribute to building up the story?

When Esin, alongside Squire and Aura Lounasmaa, listened to the narratives told by refugees in educational contexts - for instance, within the "Life Stories" university short courses and the visual arts workshops CNR offered in the Calais "Jungle" refugee camp, ${ }^{1}$ and within the Open Learning Initiative for Refugees and Asylum seekers ${ }^{2}$ (OLIVE) workshops in London - there was the urge to consider storytelling as a strategy to challenge the dominant European discourses on refugees and migration. While narratives were, sometimes intentionally and at other times less explicitly, deployed as such a strategy, often they had little power to effect that strategy; and frequently, too, they were framed differently: told by camp inhabitants to and for themselves, their families, and their friends and communities, rather than formulated within and addressed to a European context (Godin et al., 2017; Esin \& Lounasmaa, 2020; Hall et al., 2019).

Personal narratives always constitute a challenge to, but are not independent from, mainstream narratives: this is the connection. Even if storytellers position themselves simply in response to what is available, their narratives raise challenging questions about those broader narratives. In one of the OLIVE photography workshops, one of the participants, Shakib, produced a series of pictures, taken daily, about waiting for the post to arrive with a letter from the Home Office giving news about his status. The emptiness in those photos was striking for Esin. ${ }^{3}$ They might be depicting the simple fact of "Waiting," as the photographer titled the image, but for the audience, this image may also be a portrayal of the agony of waiting for an asylum seeker. Isn't that a challenge for the reader?

Reflexivity has remained a part of Esin's work through the various research environments she has shared with other researchers. But how

\footnotetext{
${ }^{1}$ https://educatingwithoutborders.wordpress.com/

${ }^{2}$ https://www.uel.ac.uk/research/olive

${ }^{3}$ https://displacesblog.wordpress.com/2017/06/30/shakib/
} 
exactly has the practice of reflexivity in research worked in narrative inquiry? Answering this question was about looking into the investigator behind a narrative. As Riessman (2015b) discusses, in narrative studies, it is the link between the personal narrative and reflexivity that assists the researcher in exploring the meaning making process (p. 221). Disclosure and reflection become inseparable to the narrative in this mode (p. 225). The reader/author/broader audiences need to know about the process in which the personal narrative is constituted-how those who are involved in storytelling become part of the dialogic process. For Esin, this process is linked to the ethical relationship between members of a research environment, including the audiences.

There are various ways to examine the researcher in research contexts. However, over-emphasizing the researcher in context should not be the main concern of narrative analysts at the expense of participants' meanings, as Riessman emphasizes (Doyle, 2013, cited in Riessman, 2015b). Reflexivity in research should rather serve a better understanding of narratives.

Narrative researchers have been challenged differently about their positioning where they are practitioners/facilitators in projects in which they listen to personal narratives, not only as researchers. In such work, reflexivity becomes a part of the political process. The participants and the audience are more than entitled to know about each other's views and assumptions, and about how they can (or cannot) deal with the relational construction of the research field. This examination can be placed under the umbrella of reflexivity by paying attention to the visceral aspects of relationships in research in order to make sense of the narratives. Esin and Lounasmaa (2020) have written about the necessity of considering relational ethics in connection with using multiple modes of narratives in education and research with refugee residents of the Calais camp and with refugees in London. When there were linguistic and cultural barriers to making sense of narratives, it was necessary to constitute visual and contextual narratives about the lives of participants. More importantly, it was important to raise questions on the relations inside and outside the projects. That relationality involved looking at the meanings in narratives within the interactional context of the educational projects. Examining the circumstances under which the personal narratives were constructed opened up different paths for us to explore. This perspective involved a reflexive approach to our (as facilitators) positioning and ethical stance in the field (Esin \& Lounasmaa, 2020). 
As Riessman (2015a and earlier) argued, historicity and social location are important aspects for telling and reading a personal narrative. When we listened to the narratives of refugees from the Calais camp, it was not possible to make sense of storytellers' meanings about living in an unrecognized camp without knowing the historical conditions. We constantly asked a question, though: What were the dynamics of the relationships in the camp that led to the emergence of, for instance, romanticized or critical stories? Those of us who worked with participants in the camp were able to question the gendered power relations, the invisibility of women in public spaces responding to the patriarchal expectations of, and requirements for, protection. We were also able to view the hegemony of particular political groups in the camp. However, our questioning also necessitated deeper understanding of what storytellers meanings were. Similar to Riessman's repositioning in relation to South Asian women's narratives of fertility, personal narratives are to be read within a network of relations, but also, still, as personal narratives.

There is no straightforward answer to any of the questions narrative scholars may raise. However, Riessman's discussions on positioning, historical locations, and reflexivity, and about how a story (even about the past) is rebuilt in interaction have been critical for researchers/facilitators in building their understanding of narratives.

\section{Narrative Associations: Moving "Outside" the Narrative Research Field?}

Some of the implications of Riessman's (2008) ideas about the pathways of narrative knowledge, discussed above, are that they open up the narrative field itself to other dialogues-less, in this case, by negotiating relationships in detailed process and analysis, but more provisionally, by suggesting associations. These moves are not so much shifts to the "outside" of the narrative field, though they may appear in that way. Rather, they involve a different, alter-geometry of narrative research lines, that reconfigure the field of narrative inquiry.

First, Riessman's ideas suggest that we produce narrative research as a set of interdisciplinary practices, always characterized by change and creativity. This suggestion is particularly important at a time when "interdisciplinarity," "change," and "creativity" of certain managed, profitable kinds are being fetishized within academic institutions. Riessman's work reminds us of what such unruly, connective processes 
really look like. Squire's (2013) work on HIV narratives, for instance, has moved between psychology, sociology, health, and development framings, with narrative method as one of the infiltrative routes. In positioning research within a dialogue between participants' and researchers' own stories, as described above, it becomes impossible to contain stories of the "psychosocial" matrix of lives lived with HIV in the UK and South Africa alike, from also entering into the fields of, for example, economic and political marginalization. More broadly, Squire's, Esin's, Lounasmaa's and Hall's work with refugees facilitating higher education access (Esin \& Lounasmaa, 2020; Hall et al., 2017) has indicated not only the relational ethics of narrative "research" in connection to political projects, but also the more general inextricability of that research from the often more implicit academic and policy framings within which it is pursued. If, for example, we were doing this research in a purely academic way, outside of the educational access context, we would by default be failing to engage with the demand for educational access which refugees frequently express, as well as ignoring their legal right to it and the possibility, indeed the ethical requirement we have, as educators, to respond to that demand.

Second, Riessman has, as mentioned above, consistently explicated narrative as multimodal, a framing that is becoming increasingly generative within narrative research. This framework allows, not only for narrative research to address different kinds of relationality among participants, researchers, and audiences, as previously described, but also for it to pay attention to the specificities of modalities. The possibilities offered by visual, performance, and poetic narratives to forced migrants who are learning European languages, for example - as indeed to many research participants generally - are symbolic fluency, emotionality, socio-historically rooted resourcefulness or "cultural capital," and audience reach, at a moment when those properties are less likely to characterize their European-language conversations or prose writing (Esin \& Lounasmaa, 2020; Esin \& Squire, 2013). Elliott, O'Connell, and Squire's (2017) work on "mummy blogs" has found that blog platforms can provide UK women, whose possibilities of living and expression are restricted in rather different ways (economically, but also by normative motherhood narratives) with routes towards subtly transgressive narratives that use the multimodality of blogs to afford resistance and normality alongside each other, as well as allowing for the women to profit to some extent from their representational work. 
Third, there is constantly both implicit and explicit attention within Riessman's work to narrative as language or, more broadly, signification, first of all. This focus enables the specificity of her work's concern with narrative, while at the same time characterizing the contents of that specificity as itself fluid. Squire has applied this focus in work that identifies the particular rhetorics that can enable narrative connection in the stories people with HIV tell about their lives-for instance, the trope of simile, as well as genres of "family" story, conversion and testimony, and "coming out" (Squire, 2013). In Esin and Squire's work on visual autobiographies produced by people living in a highly socioeconomically unequal area of East London (Esin \& Squire, 2013) young people were able to deploy graffiti-derived styles to present narratives of danger, community, and resistance with an intensity that verbal accounts-or more generalized forms of visual self-portrait - could not attain.

Fourth, Riessman's work is at all times attentive to context and to where that takes us - to the detailed considerations of research context considered above, but also to contexts that exist largely outside the research: everyday and larger political engagements in the present, reflecting on the past, and imagining what is to come. This is "joined-up" narrative research, never content with itself and always curious. It is the kind of work that many narrative researchers in post-crisis or post-conflict situations, or interested in narrative as a driver of social justice now, often drawing explicitly on Riessman's work, pursue - even though in so doing, the narrative focus of their work may apparently become distributed, within considerations of history, politics, or art; or theoretically, within the "intersectional" or the "decolonial" (Squire, 2020). Squire's current work on HIV narratives, for example, has shifted its focus to the resource contexts of food, housing, transport, and sanitation, as well as medical and psychosocial support, to generate larger narrative maps of how health and illness are lived.

\section{Conclusion}

The ways in which Riessman's work has developed narrative research as relational and associational practice (technologies of creative meaning-making) have contributed, along with the work of others in the field - for her work, as she herself, is constitutionally collaborative - to a research approach that is exemplary, in its openness and generativity, for contemporary and future social research. Riessman's writings are research events we may meet with at many places on our academic 
paths - in narrative or qualitative research, health research, social work research, and feminist research. In all of these places, Riessman has shown us new directions, diversions, and dispersions, and has pointed out the dialogic connections between routes of thinking that bring them together. We can learn from her how narrative research can work within a relational and associative framework that has powerful and creative effects in the narrative field and beyond.

\section{References}

Elliott, H., O’Connell, R., \& Squire, C. (2017). Narratives of normativity and permissible transgression: Mothers' blogs about mothering, family and food in resource-constrained times. Forum: Qualitative Social Research, 18(1). Retrieved from http:/www.qualitative-research.net/index.php/fqs/article/ view $/ 2775$

Esin, C. (2017). Telling stories in pictures: Constituting processual and relational narratives in research with young British Muslim women in East London. Forum: Qualitative Social Research,(18)1. Retrieved from https://www.qualitative-research.net/index.php/fqs/article/view/2774

Esin, C. (2009). Construction of sexuality in the narratives of well-educated young women in Turkey [Doctoral dissertation, University of East London].

Esin, C., \& Lounasmaa, A. (2020). Narrative and ethical (in)action: Creating spaces of resistance with refugee-storytellers in the Calais "Jungle" camp, International Journal of Social Research Methodology. DOI: $10.1080 / 13645579.2020 .1723202$

Esin, C., \& Squire, C. (2013). Visual autobiographies in East London: Narratives of still images, interpersonal exchanges, and intrapersonal dialogues. Forum: Qualitative Social CResearch, 14(2). Retrieved from https:/www.qualitative-research.net/index.php/fqs/article/view/1971

Godin, M., Hansen, K., Lounasmaa, A., Squire, C., \& Zaman, T. (Eds.). (2017). Voices from the "Jungle": Stories from the Calais refugee camp. Pluto Press.

Hall, T., Lounasmaa, A., \& Squire, C. (2019). From margin to centre? Practising new forms of European politics and citizenship in the Calais "Jungle." in C. Cantat, E. Sevinin, E. Maczynska, \& T. Birey (Eds.), Challenging the political across borders: Migrants' and solidarity struggles (pp. 99-128). Central European University Publishers.

Riessman, C. K. (1993). Narrative analysis. Sage. Riessman, C.K. (2000). Stigma and everyday resistance practices: Childless women in South India. Gender and Society, 14, pp. 111-35.

Riessman, C. K. (2002). Analysis of personal narratives. In J. Gubrium \& J. Holstein (Eds.), Handbook of interview research: Context and method. Sage.

Riessman, C. K. (2008). Narrative methods for the human sciences. Sage.

Riessman, C. K. (2015a). Ruptures and sutures: Time, audience and identity in an illness narrative. Sociology of Health \& Illness, 37(7), 1055-1071.

Riessman, C. K. (2015b). Entering the hall of mirrors. In A. De Fina and A. Georgakopoulou (Eds.), The handbook of narrative analysis (pp. 219-238). Wiley. 
Squire, C. (Ed). (2020). Stories changing lives: Narratives and paths toward social change. Oxford University Press.

Squire, C. (2013). Living with HIV and ART: Three-letter lives. Palgrave.

Williams, L., Labonte, R., \& O’Brien, M. (2003). Empowering social action through narratives of identity and culture. Health Promotion International, 18(1), 3340 .

Cigdem Esin, PhD, is Senior Lecturer in Psychosocial Studies and Co-Director of the Centre for Narrative Research at the University of East London. Her research interests are in narrative methodologies, interconnections between power networks and personal narratives, migrant and refugee narratives, and visual storytelling.

Corinne Squire, $\mathrm{PhD}$, is Professor of Social Sciences and Co-Director of the Centre for Narrative Research at the University of East London. She is also Research Associate at the University of the Witwatersrand. Her research interests are in narrative theory and methods, subjectivities in popular culture, refugee education and politics, and HIV and citizenship. 